\section{Isotopic Determination and Optimum} Reaction Conditions of Pantothenic Acid Synthetase

\author{
Kazutaka Miyatake, Yoshihisa Nakano \\ and Shozaburo KITAOKA
}

\section{Department of Agricultural Chemistry, University of Osaka Prefecture, Sakai, Osaka 591}

Received October 16, 1972

Partial purification and properties of pantothenic acid synthetase (D-pantoate: $\beta$-alanine ligase (AMP), E.C. 6.3.2.1) which catalyzes the condensation of Dpantoic acid and $\beta$-alanine in the presence of ATP have been reported by Mass, ${ }^{11}$ Mass and Novelli ${ }^{2)}$ and Pfleiderer et al. ${ }^{3 \sim 67}$ with the enzyme preparations from Escherichia coli. The former group employed a microbioassay technique with a pantothenate-auxotrophic mutant of $E$. coli $i^{7}$ for the determination of the enzyme activity while the latter a spectrometric method ${ }^{31}$ in a complicated system of enzyme reactions, in which AMP formed during the condensation was converted into ADP (myokinase) and then into ATP (pyruvate kinase) and the liberated pyruvate was allowed to oxidize NADH in the presence of lactate dehydrogenase. These methods, though elaborated, lack satisfactory simplicity, speed and other conveniences for studying this enzyme.

In the experiments reported here, which constitute a part of detailed studies on the biosynthesis of pantothenic acid in this laboratory, we introduced an isotopic method of determining the activity of pantothenic acid synthetase by the use of $\beta$-alanine- $1{ }^{-14} \mathrm{C}$, and the radioactive pantothenic acid formed was determined after separation by ion-exchanger column chromatography by measuring its radioactivity. By using this technique, simpler and speedier than the reported ones, we studied on some properties of this enzyme in a 35 -fold purified preparation from $E$. coll $\mathrm{B}$ and revised the optimum $\mathrm{pH}$ and temperature of the enzyme reaction, which had been reported previously. Apparent $K m$ values for the substrates under these conditions are presented also.

Materials. Pantothenic acid synthetase was isolated from the acetone powder of $E$. coli B (IFO 13168), which had been cultured at $30^{\circ} \mathrm{C}$ for $20 \sim 24 \mathrm{hr}$ with aeration in a minimum synthetic medium ${ }^{81}$ at $\mathrm{pH} 7.0$, by homogenizing with glass homogenizer in 10 volumes of tris- $\mathrm{HCl}$ buffer $(0.01 \mathrm{M}, \mathrm{pH} 7.2)$, centrifuging at $5,000 \times g$ for $15 \mathrm{~min}$, and dialyzing the supernatant against distilled water. This crude preparation was purified by treatment with $0.2 \sim 0.7$ saturation of $\left(\mathrm{NH}_{4}\right)_{2} \mathrm{SO}_{4}$, Sephadex G-100 chromatography, DEAESephadex (A-50) chromatography, Sephadex G-150 chromatography, DEAE-Sephadex (A-50) rechromatography and treatment with $0.4 \sim 0.6$ saturation of $\left(\mathrm{NH}_{4}\right)_{2} \mathrm{SO}_{4}$, in succession, to obtain a 35 -fold purified enzyme preparation.

$\beta$-Alanine- $1{ }^{14} \mathrm{C}$ was a product of International Chemical and Nuclear Co. $(0.25 \mathrm{mCi} / 4.7 \mathrm{mg})$. Other chemicals were supplied from Nakarai Chemicals Ltd, Kyoto.

Enzyme reaction. The reaction mixture contained $5 \mu \mathrm{M}$ ATP, $20 \mu \mathrm{M}$ potassium D-pantoate, $10 \mu \mathrm{M} \mathrm{MgSO}$. $7 \mathrm{H}_{2} \mathrm{O}, 50 \mu \mathrm{M}$ glycine buffer $(\mathrm{pH} 10.0), 0.1 \mu \mathrm{Ci} \beta$-alanine${ }^{1-14} \mathrm{C}$ (for isotopic determination) or $20 \mu \mathrm{M}$ cold $\beta$ alanine (for bioassay) and $1 \sim 400 \mu \mathrm{g}$ of the enzyme protein, and distilled water was added to make the total volume $1 \mathrm{cc}$. The reaction mixture was incubated at $30^{\circ} \mathrm{C}$ for $15 \sim 60 \mathrm{~min}$ with shaking, and then the reaction was stopped by heating at $100^{\circ} \mathrm{C}$ for $5 \mathrm{~min}$ after adjusting $\mathrm{pH}$ below 5 with $\mathrm{N} \mathrm{HCl}$.

Assays. In the isotopic assay the reaction mixture was charged onto a Dowex-50 ( $\mathrm{H}^{+}$form) column $(0.6 \times 6 \mathrm{~cm})$ and the synthesized, radioactive pantothenic acid was eluted with distilled water $(5 \mathrm{cc})$. The radioactivity of the eluate was measured with a gasflow counter (Aloka, model TDC 2). The radioactive product of the enzyme reaction was identified to be pantothenic acid by paper chromatographic examination of the eluate.

Microbial assay was performed by the use of a pantothenic acid-requiring mutant ${ }^{9}$ of $E$. coli (No, 229) which had been cultured in the Davis medium ${ }^{10)}$ containing $1 \mathrm{mg}$ of pantothenic acid per 1 liter. This assay could determine $0.5 \sim 500 \mu \mathrm{g}$ of pantothenic acid.

Comparison of the isotopic and bioassay methods. Both methods were compared to each other in assessing the effect of ATP concentration on the activity of pantothenic acid synthetase (Table I). Similar

Table I. Effect of ATP Concentration on the Enzyme Activity as Determined by the ISOTOPIC AND BIOASSAY METHODS

The activities are given relative to the one observed with $5.0 \mu \mathrm{M}$ ATP in each method.

\begin{tabular}{ccc}
\hline $\begin{array}{c}\text { ATP } \\
\text { Concn. } \\
(\mu \mathrm{M})\end{array}$ & \multicolumn{2}{c}{ Relative enzyme activity } \\
\cline { 2 - 3 } & $\begin{array}{c}\text { Isotopic } \\
\text { method }\end{array}$ & $\begin{array}{c}\text { Bioassay } \\
\text { method }\end{array}$ \\
\hline 0.1 & 22 & - \\
0.5 & 55 & 52 \\
1.0 & 72 & 70 \\
2.0 & 85 & 84 \\
5.0 & 100 & 100 \\
\hline
\end{tabular}


Table II. $K m$ Values (M) for Substrates Here Found and Reported Previously

\begin{tabular}{rrrrr}
\hline$\beta$-Alanine & Pantoic acid & \multicolumn{2}{c}{ Reaction conditions } & Ref. \\
\hline $5.6 \times 10^{-5}$ & $1.2 \times 10^{-4}$ & $\mathrm{pH} 10.0$ (glycine); & $30^{\circ} \mathrm{C}$ & \\
$3.8 \sim 7.4 \times 10^{-4}$ & $1.5 \sim 3.5 \times 10^{-3}$ & $\mathrm{pH} 8.5$ (tris-HCl); $25^{\circ} \mathrm{C}$ & 1 ) \\
$9.5 \times 10^{-4}$ & $6.6 \times 10^{-4}$ & $\mathrm{pH} 8.5$ (tris-HCl); $25^{\circ} \mathrm{C}$ & 3 ) \\
\hline
\end{tabular}

results were obtained by both methods of determination, but the amount of enzyme protein here used was $0.5 \mu \mathrm{g}$ in the isotopic method while it was $3 \mu \mathrm{g}$ in the bioassay method. In addition, the former method was so sensitive as able to determine the effect of $0.1 \mu \mathrm{M}$ of ATP in this experiment while the latter was sensitive only down to $0.5 \mu \mathrm{M}$.

Figure 1 shows the time course of the enzyme reaction with different enzyme concentrations as determined by the isotopic method. The formation of labeled pantothenic acid is linearly proportional to the reaction time up to $30 \mathrm{~min}$ and to the enzyme concentration at $0.5 \sim 1.5 \mu \mathrm{g} /$ tube. With the crude extract the linearity existed up to $400 \mu \mathrm{g}$ enzyme protein/tube for $1 \mathrm{hr}$.

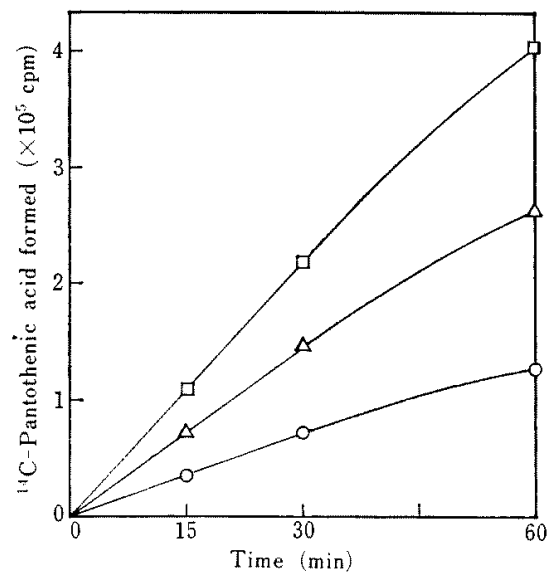

Fig. 1. Time Course of Enzyme Reaction at Different Enzyme Concentrations.

$\bigcirc-\bigcirc 0.5, \triangle-\triangle 1.0$, and $\square-\square 1.5 \mu \mathrm{g}$ enzyme protein $/$ tube.

Optimum $p H$ and temperature. By using this isotopic method, the effects of $\mathrm{pH}$ and temperature on the reaction of pantothenic acid synthetase were studied. Figure 2 shows the effect of $\mathrm{pH}$. The optimum $\mathrm{pH}$ was found at 10.0 in glycine- $\mathrm{KOH}-\mathrm{KCl}$ buffer $(50 \mathrm{~mm})$. This value is considerably different from $\mathrm{pH} 8.50$ (Tris- $\mathrm{HCl}$ buffer, $100 \mathrm{~mm}$ ) as reported to be optimum by Mass, ${ }^{11}$ at which only $55 \%$ of the enzyme activity at the optimum pH (and optimum temperature) here found was observed. The enzyme

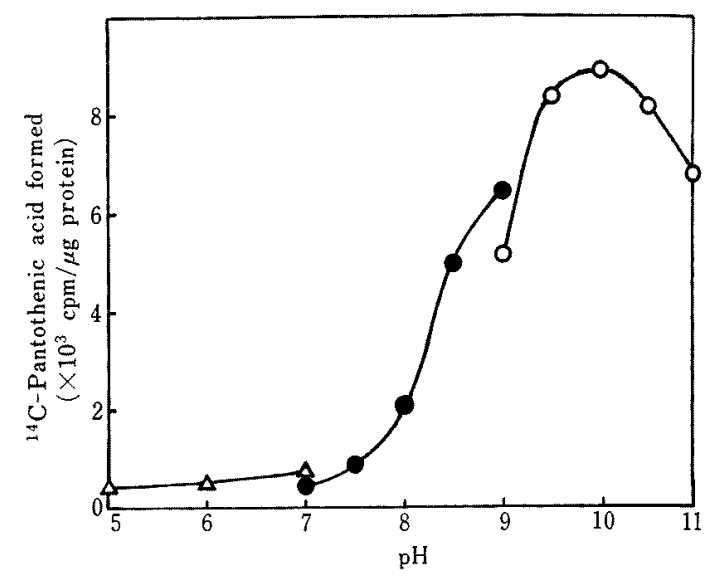

Fig. 2. Effect of $\mathrm{pH}$.

Reactions were conducted at $30^{\circ} \mathrm{C}$ for $30 \mathrm{~min}$ with shaking (120 strokes/min); $1 \mu \mathrm{g}$ enzyme protein was contained per tube.

Buffers: $\triangle-\triangle$ Potassium phosphate, $\longrightarrow$ Tris- $\mathrm{HCl}$, $\mathrm{O}-\mathrm{O}$ Glycine-KOH-KCl .

was most active at $30^{\circ} \mathrm{C}$. Against the activity at this optimum temperature, the enzyme was $90 \%$ active at $37^{\circ} \mathrm{C}$ and $60 \%$ active at $45^{\circ} \mathrm{C}$. Mass ${ }^{11}$ and Novelli111 reported the optimum temperature of this enzyme to be $25^{\circ} \mathrm{C}$.

This enzyme preparation required a divalent ion, $\mathrm{Mg}^{2+}$ or $\mathrm{Mn}^{2+}$, and a monovalent ion, $\mathrm{K}^{+}$or $\mathrm{NH}_{4}{ }^{+}$, as activators, in agreement with the reported results. ${ }^{11}$

$K m$ Values. Under the optimum conditions here found for the reaction of pantothenic acid synthetase, the apparent $K m$ values for both substrates were calculated and are given in Table II together with the reported values for the purpose of comparison. The data indicate that the newly found conditions afford the enzyme with higher affinities to the substrates.

\section{REFERENCES}

1) W. K. Mass, J. Biol. Chem., 198, 23 (1952).

2) W. K. Mass and G. D. Novelli, Arch. Biochem. Biophys., 43, 236 (1953).

3) G. Pfleiderer, A. Kreiling and T. Wieland, Biochem. $Z$, 333, 302 (1960).

4) idem, ibid., 333, 308 (1960). 
5) T. Wieland, A. Kreiling, W. Buck and G. Pfleiderer, ibid., 333, 311 (1960).

6) A. Kreiling, W. Ludwig and G. Pfleiderer, ibid., 336, 241 (1962).

7) W. K. Mass and B. D. Davis, J. Bacteriol., 60, 733 (1950).

8) B. D. Davis, Proc. Natl. Acad. Sci. U. S., 35, 1
(1949).

9) K. Kawachi, Bitamin, 21, 21 (1960).

10) B. D. Davis and E. S. Mingioli, J. Bacteriol., 60, 17 (1950).

11) G. D. Novelli, "Methods in Enzymology," Vol. II, ed. by S. P. Colowick and N. O. Kaplan, Academic Press, Inc., New York, 1955, p. 619. 